Department of Economics- FEA/USP

\title{
The Role of Brazilian Regions in the Global Value Chain
}

ERIK DIETZENBACHER

JOAQUIM J.M. GUILHOTO

DENISE IMORI

WORKING PAPER SERIES № 2013-15 


\title{
DEPARTMENT OF ECONOMICS, FEA-USP \\ WORKING PAPER № 2013-15
}

\section{The Role of Brazilian Regions in the Global Value Chain}

\author{
Erik Dietzenbacher (h.w.a.dietzenbacher@rug.nl) \\ Joaquim J.M. Guilhoto (guilhoto@usp.br) \\ Denise Imori (denise.imori@usp.br)
}

Research Group: NEREUS

\begin{abstract}
:
In the last couple of decades, production processes have been characterized by their fragmentation, which crosses the borders of countries more and more. This coincides with the common viewpoint that products and services are now made in global value chains and that 'trade in value added' might be a better approach for the measurement for international trade. The same applies at the regional level, and perhaps even to a larger extent. The present paper analyzes the role of Brazilian states in the global value chain. Since fragmentation of production processes leads to an interdependent structure which has to be accounted for, the input-output methodology seems especially suitable. Therefore, in its empirical application, the paper combines a world input-output table covering 40 countries (and the rest of the world as a $41^{\text {st }}$ country) with an inter-regional input-output table covering each of the Brazilian states, for the year 2008. Our results show that the average country trades approximately twice as much in value added (as a share of country's value added) than Brazil: the participation of Brazil in the global value chain is somewhat limited. We notice, however, important differences among states, both in terms of trade volume and of relevant industries that account for the generation of value added. The paper also further analyzes the Brazilian value chain and the trade relations of Brazilian states with China and USA, exploring the regional heterogeneities involving such relations.
\end{abstract}

Keywords: International trade, input-output analysis, regional economics

JEL Codes: F10, R15, R11 


\title{
The Role of Brazilian Regions in the Global Value Chain
}

\section{Erik Dietzenbacher, Joaquim J.M. Guilhoto and Denise Imori}

Erik Dietzenbacher, University of Groningen, Faculty of Economics, PO Box 800, 9700 AV

Groningen, The Netherlands, h.w.a.dietzenbacher@rug.nl

Joaquim J.M. Guilhoto and Denise Imori, University of São Paulo, Departamento de Economia - FEA - USP, Brazil, guilhoto@ usp.br and denise.imori@usp.br

\begin{abstract}
In the last couple of decades, production processes have been characterized by their fragmentation, which crosses the borders of countries more and more. This coincides with the common viewpoint that products and services are now made in global value chains and that 'trade in value added' might be a better approach for the measurement for international trade. The same applies at the regional level, and perhaps even to a larger extent. The present paper analyzes the role of Brazilian states in the global value chain. Since fragmentation of production processes leads to an interdependent structure which has to be accounted for, the input-output methodology seems especially suitable. Therefore, in its empirical application, the paper combines a world input-output table covering 40 countries (and the rest of the world as a $41^{\text {st }}$ country) with an inter-regional input-output table covering each of the Brazilian states, for the year 2008. Our results show that the average country trades approximately twice as much in value added (as a share of country's value added) than Brazil: the participation of Brazil in the global value chain is somewhat limited. We notice, however, important differences among states, both in terms of trade volume and of relevant industries that account for the generation of value added. The paper also further analyzes the Brazilian value chain and the trade relations of Brazilian states with China and USA, exploring the regional heterogeneities involving such relations.
\end{abstract}

Keywords: International trade, input-output analysis, regional economics JEL Codes: F10, R15, R11 


\section{Introduction}

In the recent past, production processes have increasingly become sliced up into ever smaller parts (or fragmented). Many of these parts are outsourced to specialized subcontractors that are more and more located in foreign countries (i.e. offshoring). This has led to an upsurge of trade in intermediate products, which corresponds to Baldwin's (2006) "second wave of global unbundling" where the location of the production of intermediate inputs differs from the location of the production of the final products. ${ }^{1}$ Theories to explain the relocation of the production of intermediate inputs to other countries have been developed e.g. by Grossman and Rossi-Hansberg (2008) and Costinot et al. (2013).

Today's products and services are no longer produced within a single country. Instead, they are made in global supply chains, or global value chains. That is, countries import intermediate goods and raw materials, to which they add one or more layers of value after which they sell the product (often to a foreign producer who adds the next layer). Standard trade figures that measure the value of imports and exports do not reflect any more what is really happening. This has also attracted the attention of policy makers. For example, according to EU Commissioner for Trade Karel De Gucht: 2 "The country that exports the final product is artificially credited with having created all of its value, even if in reality it only assembled ready-made parts. ... This is a bit like the final runner in a relay team getting a gold medal while his teammates get silver and bronze. It doesn't take account of the fact that the final result is the product of a joint effort." Recently, Pascal Lamy (Director-General of the WTO) launched jointly with the OECD, the "made in the world" initiative and proposed "trade in value added" as a better approach for the measurement for international trade (see OECD-WTO, 2012).

The same applies at the regional level, and perhaps even to a larger extent. Due to locational advantages (e.g. the presence of a seaport and/or an airport), one region is typically responsible for most of the imports and exports of a country. Even if the production of some export goods takes place entirely within the country, it is likely that other regions than the exporting region also have contributed to the value of the exports. For example by supplying intermediate inputs and raw materials that go into the final product that is sold abroad. Next to international fragmentation, also interregional fragmentation plays a role when focusing on regions.

The present paper analyzes the role of Brazilian regions in the global value chain. We will do this by answering the question: How much value added generated in, for example, the state of Pernambuco is embodied in the "consumption" bundle of, for example, Canada? This gives us the export of value added from Pernambuco to Canada. It should be stressed that the "consumption" bundle includes household consumption, government expenditures, gross fixed capital formation, and changes in inventories. It should also be stressed that the Canadian consumption bundle includes imported goods from other countries, such as the US. Indirectly, these goods may include value added from Pernambuco. So, in principle, it may be the case that Pernambuco does not export to Canada but that some of its value added is still embodied in Canadian consumption (for example through US exports that are produced using imports from Pernambuco). In the same fashion, we will also calculate the import of Canadian value added by Pernambuco.

\footnotetext{
${ }^{1}$ The first wave of global unbundling refers to the separation of the location of consumption and the location of production were separated, which led to increased trade in final products.

${ }^{2}$ Available at: http://trade.ec.europa.eu/doclib/docs/2012/april/tradoc 149337.pdf.
} 
Whereas the methodology to calculate the trade in value added is well-known (see references), the availability of data used to be a problem. ${ }^{3}$ In recent years, however, several groups of researchers have developed so-called world input-output tables (WIOTs). These are interregional Isard-type input-output tables with countries instead of regions. The now available WIOTs typically include a large number of individual countries and a "country" that reflects the rest of the world. ${ }^{4}$ The present paper combines the WIOT from the WIOD project, which includes Brazil as one of its countries, with an inter-regional input-output table (IRIOT) for Brazil. ${ }^{5}$

\section{Methodology}

In our analysis, we will combine a world input-output table (WIOT) with an interregional input-output table (IRIOT). For the empirical application, we will use the WIOT for 2008 that was constructed in the WIOD project (see Dietzenbacher et al., 2013). It is a full inter-country input-output (IO) table covering 40 countries and the rest of the world as a $41^{\text {st }}$ country. One of the countries included is Brazil. The IRIOT for 2008 is for Brazil and covers the 27 Brazilian states. Both the WIOT and the IRIOT were aggregated to 28 compatible industries. The description of regions and industries of the model can be found in the Appendix.

In this section, we will outline the methodology using a much smaller case as an example. Without loss of generality we will employ a WIOT for a world that consists of three countries $(R, S, T)$. For country $T$ we have an IRIOT, distinguishing between two regions (east $E$ and west $W$ ). The WIOT is given in Figure 1 and the IRIOT in Figure 2.

Figure 1. The world input-output table

\begin{tabular}{|l|ccc|ccc|c|}
\hline & \multicolumn{3}{|c|}{ Intermediate use } & \multicolumn{3}{c|}{ Final use } & Gross \\
& in $R$ & in $S$ & in $T$ & in $R$ & in $S$ & in $T$ & Output \\
\hline Product flows from & & & & & & & \\
country $R$ & $\mathbf{Z}^{R R}$ & $\mathbf{Z}^{R S}$ & $\mathbf{Z}^{R T}$ & $\mathbf{c}^{R R}$ & $\mathbf{c}^{R S}$ & $\mathbf{c}^{R T}$ & $\mathbf{x}^{R}$ \\
country $S$ & $\mathbf{Z}^{S R}$ & $\mathbf{Z}^{S S}$ & $\mathbf{Z}^{S T}$ & $\mathbf{c}^{S R}$ & $\mathbf{c}^{S S}$ & $\mathbf{c}^{S T}$ & $\mathbf{x}^{S}$ \\
country $T$ & $\mathbf{Z}^{T R}$ & $\mathbf{Z}^{T S}$ & $\mathbf{Z}^{T T}$ & $\mathbf{c}^{T R}$ & $\mathbf{c}^{T S}$ & $\mathbf{c}^{T T}$ & $\mathbf{x}^{T}$ \\
\hline Value added & $\left(\mathbf{v}^{R}\right)^{\prime}$ & $\left(\mathbf{v}^{S}\right)^{\prime}$ & $\left(\mathbf{v}^{T}\right)^{\prime}$ & & & & \\
\hline Total inputs & $\left(\mathbf{x}^{R}\right)^{\prime}$ & $\left(\mathbf{x}^{S}\right)^{\prime}$ & $\left(\mathbf{x}^{T}\right)^{\prime}$ & & & & \\
\hline
\end{tabular}

For example, $\mathbf{Z}^{R S}$ is an $n \times n$ matrix and its typical element $z_{i j}^{R S}$ indicates the delivery of intermediate inputs from industry $i$ in country $R$ to industry $j$ in country $S .{ }^{6}$ Note that $i, j=1$, $\ldots, n$ where $n$ is the number of industries. In case $R \neq S$, the matrix $\mathbf{Z}^{R S}$ indicates the exports of country $R$ to industries in country $S . \mathbf{c}^{R S}$ is an $n$-element vector and its typical element $c_{i}^{R S}$

\footnotetext{
${ }^{3}$ As a matter of fact, the calculation of trade in value added is very similar to the calculation of trade in emissions, the methodology of which is known for quite some time (see, e.g. Serrano and Dietzenbacher, 2010, and other references).

${ }^{4}$ The issue 1 of volume 25 of Economic Systems Research (2013) is devoted to recent compilations of WIOTs, with contributions by references. See also GRAM etc.

${ }^{5}$ The full database from the WIOD project (including a time series of WIOTs) is publicly and free of charge available at: http://www.wiod.org/database/index.htm.

${ }^{6}$ Matrices are given in bold capital letters (e.g. $\mathbf{Z}^{R S}$ ), vectors are given in bold lower case letters (e.g. $\mathbf{x}^{R}$ ), and scalars (including matrix or vector elements) are given in italicized lower case letters (e.g. $x_{i}^{R}$ ). Vectors are columns by definition, row vectors are obtained by transposition, which is indicated by a prime (e.g. $\left.\left(\mathbf{v}^{R}\right)^{\prime}\right)$. We will use a circumflex or "hat" to indicate a diagonal matrix (e.g. $\hat{\mathbf{x}}^{R}$ ) with the elements of the corresponding vector (i.e. $\mathbf{x}^{R}$ ) on the main diagonal and all other elements equal to zero.
} 
indicates the final use (also termed final demand) in country $S$ of goods and services produced by industry $i$ in country $R$. Final use covers household and government consumption, consumption of non-profit organizations, gross fixed capital formation, and changes in inventories. Again, if $R \neq S, \mathbf{c}^{R S}$ indicates the exports of country $R$ to final users in country $S$. $\mathbf{x}^{R}$ is an $n$-element vector with its typical element $x_{i}^{R}$ indicating the gross output of industry $i$ in country $R$. Finally, $\mathbf{v}^{R}$ is an $n$-element vector and its typical element $v_{i}^{R}$ gives the value added in industry $i$ of country $R$.

Figure 2. The inter-regional input-output table

\begin{tabular}{|c|c|c|c|c|c|}
\hline & Intermediate use & Final use & \multicolumn{2}{|c|}{ Exports } & \multirow{2}{*}{$\begin{array}{c}\text { Gross } \\
\text { output }\end{array}$} \\
\hline & in $W$ & in $E$ & to $R$ & to $S$ & \\
\hline $\begin{array}{l}\text { Product flows from } \\
\quad \text { region } E \\
\text { region } W\end{array}$ & $\begin{array}{l}\mathbf{Z}^{E W} \\
\mathbf{Z}^{W W}\end{array}$ & $\begin{array}{c}\mathbf{c}^{E E} \\
\mathbf{c}^{W E}\end{array}$ & $\begin{array}{c}\mathbf{e}^{E R} \\
\mathbf{e}^{W R}\end{array}$ & $\begin{array}{l}\mathbf{e}^{E S} \\
\mathbf{e}^{W S}\end{array}$ & $\begin{array}{l}\mathbf{x}^{E} \\
\mathbf{x}^{W}\end{array}$ \\
\hline Imports & $\left(\mathbf{m}^{E}\right)^{\prime} \quad\left(\mathbf{m}^{W}\right)^{\prime}$ & $h^{W}$ & & & \\
\hline Value added & $\left(\mathbf{v}^{W}\right)^{\prime}$ & & & & \\
\hline Total inputs & $\left(\mathbf{x}^{E}\right)^{\prime} \quad\left(\mathbf{x}^{W}\right)^{\prime}$ & & & & \\
\hline
\end{tabular}

The interpretation of the matrices $\mathbf{Z}$ and the vectors $\mathbf{c}, \mathbf{x}$ and $\mathbf{v}$ is similar to the interpretation in the case of the WIOT in Figure 1. For example, $z_{i j}^{E W}$ gives the flows of goods and services from industry $i$ in region $E$ to industry $j$ in region $W, c_{i}^{E W}$ indicates the delivery by industry $i$ in region $E$ to final users in region $W$, and $x_{i}^{E}$ and $v_{i}^{E}$ give the gross output and value added in industry $i$ in region $E$. In addition, $\mathbf{e}^{E R}$ is an $n$-element export vector and its typical element $e_{i}^{E R}$ gives the total exports by industry $i$ in region $E$ to country $R$. Note that no information is available for the distribution of the exports over destinations (i.e. industries and final users in country $R$ ). The Brazilian IRIOT provides information for the total imports by each industry, i.e. without making a distinction between the countries of origin. For region $E$ for example, $\mathbf{m}^{E}$ is the $n$-element import vector and its typical element $m_{i}^{E}$ indicates the total imports by industry $i$ in region $E$. Finally, the scalar $h^{E}$ gives the total imports purchased by final users in region $E$. Again, it is not known how much each country of origin delivers to final users in $E$, just the total of these deliveries is known. It should be stressed that other import information is available (and will be used and discussed later) that is not indicated in Figure 2.

When combining the information from the WIOT and the IRIOT, we might start by constructing an enlarged input-output table. The information for country $T$ in the WIOT is then to be replaced by the information for regions $E$ and $W$ from the IRIOT. One of the problems, however, is that the information for country $T$ in the WIOT is not entirely consistent with the summation of the information for regions $E$ and $W$. Instead, we will therefore carry out the analysis by using the WIOT for calculations at the country level and using the IRIOT for calculations at the regional level, and iterating back and forth.

The question that we will start with is: What are the output levels (in countries $R$ and $S$, and regions $E$ and $W$ ) necessary to satisfy an arbitrary final demand vector? We split this question and consider the outputs necessary for arbitrary final demand vectors $\mathbf{y}^{R}$ and $\mathbf{y}^{S}$ first. We use the round-by-round approach that is common in IO analysis. In the first round, the final demands need to be produced themselves. That is, $\mathbf{y}^{R}$ in country $R$ and $\mathbf{y}^{S}$ in country $S$. In the second round we need to calculate how much inputs are required (i.e. the direct inputs). Let the input matrices be defined as usual. That is, for example, $\mathbf{A}^{R S}=\mathbf{Z}^{R S}\left(\hat{\mathbf{x}}^{S}\right)^{-1}$ with its typical element $a_{i j}^{R S}=a_{i j}^{R S} / x_{j}^{S}$ indicating the input from industry $i$ in country $R$ that goes to 
(and is measured per unit of output of) industry $j$ in country $S$. The direct inputs amount to $\mathbf{A}^{R R} \mathbf{y}^{R}+\mathbf{A}^{R S} \mathbf{y}^{S}$ in country $R$ and to $\mathbf{A}^{S R} \mathbf{y}^{R}+\mathbf{A}^{S S} \mathbf{y}^{S}$ in country $S$.

From the WIOT, it follows that the direct inputs required from country $T$ amount to $\mathbf{A}^{T R} \mathbf{y}^{R}+\mathbf{A}^{T S} \mathbf{y}^{S}$. Note that these are exports of country $T$ to country $R\left(\mathbf{A}^{T R} \mathbf{y}^{R}\right)$ and to country $S\left(\mathbf{A}^{T S} \mathbf{y}^{S}\right)$. For our analysis we would need to know the exports of region $E$ to country $R$ (i.e. $\mathbf{A}^{E R} \mathbf{y}^{R}$ ) and from region $W$ to country $R$ (i.e. $\mathbf{A}^{W R} \mathbf{y}^{R}$ ), but the input matrices $\mathbf{A}^{E R}$ and $\mathbf{A}^{W R}$ are unknown. The IRIOT, however, provides information on the average product mix of the regional exports to $R$ and to $S$. By deriving export shares, we estimate how much of the exports to $R$, for example, originates from region $E$ and how much from $W$. Let the vector $\boldsymbol{\sigma}^{E R}$ denote the vector of export shares. Its elements are defined as follows.

$$
\sigma_{i}^{E R}=e_{i}^{E R} /\left(e_{i}^{E R}+e_{i}^{W R}\right)
$$

which indicates the share of the exports of product $i$ to country $R$ that stems from region $E$. The shares from region $W$ are defined similarly and the shares add to one (i.e. $\sigma_{i}^{E R}+\sigma_{i}^{W R}=$ 1).

We assume that the export shares apply irrespective of the industry of destination in country $R$. Our estimate (indicated by a tilde) for the input coefficients then yields $\tilde{a}_{i j}^{E R}=$ $\sigma_{i}^{E R} a_{i j}^{T R}$. The direct inputs from region $E$ (which are exported to country $R$ ) then become $\widetilde{\mathbf{A}}^{E R} \mathbf{y}^{R}=\widehat{\boldsymbol{\sigma}}^{E R} \mathbf{A}^{T R} \mathbf{y}^{R}$, and those from region $W$ are given by $\widetilde{\mathbf{A}}^{W R} \mathbf{y}^{R}=\widehat{\boldsymbol{\sigma}}^{W R} \mathbf{A}^{T R} \mathbf{y}^{R}$.

In the same fashion, the exports of country $T$ to country $S\left(\mathbf{A}^{T S} \mathbf{y}^{S}\right)$ in this first round must be split into the exports from region $E$ and those from region $W$, which are estimated using the export shares for exports to $S$. That is, using $\sigma_{i}^{E S}=e_{i}^{E S} /\left(e_{i}^{E S}+e_{i}^{W S}\right)$ and $\sigma_{i}^{W S}=$ $e_{i}^{W S} /\left(e_{i}^{E S}+e_{i}^{W S}\right)$, the exports from region $E$ and from region $W$ are estimated as $\widetilde{\mathbf{A}}^{E S} \mathbf{y}^{S}=$ $\widehat{\boldsymbol{\sigma}}^{E S} \mathbf{A}^{T S} \mathbf{y}^{S}$ and $\widetilde{\mathbf{A}}^{W S} \mathbf{y}^{S}=\widehat{\boldsymbol{\sigma}}^{W S} \mathbf{A}^{T S} \mathbf{y}^{S}$. The direct inputs necessary for the final demand vectors $\mathbf{y}^{R}$ and $\mathbf{y}^{S}$ are given by

$$
\left[\begin{array}{cc}
\mathbf{A}^{R R} & \mathbf{A}^{R S} \\
\mathbf{A}^{S R} & \mathbf{A}^{S S} \\
\widetilde{\mathbf{A}}^{E R} & \widetilde{\mathbf{A}}^{E S} \\
\widetilde{\mathbf{A}}^{W R} & \widetilde{\mathbf{A}}^{W S}
\end{array}\right]\left(\begin{array}{c}
\mathbf{y}^{R} \\
\mathbf{y}^{S}
\end{array}\right)=\left[\begin{array}{cc}
\mathbf{A}^{R R} & \mathbf{A}^{R S} \\
\mathbf{A}^{S R} & \mathbf{A}^{S S} \\
\widehat{\boldsymbol{\sigma}}^{E R} \mathbf{A}^{T R} & \widehat{\boldsymbol{\sigma}}^{E S} \mathbf{A}^{T S} \\
\widehat{\boldsymbol{\sigma}}^{W R} \mathbf{A}^{T R} & \widehat{\boldsymbol{\sigma}}^{W S} \mathbf{A}^{T S}
\end{array}\right]\left(\begin{array}{c}
\mathbf{y}^{R} \\
\mathbf{y}^{S}
\end{array}\right)
$$

The second question is similar to the first one, namely what are the output levels (in countries $R$ and $S$, and regions $E$ and $W$ ) necessary to satisfy arbitrary final demand vectors $\mathbf{y}^{E}$ and $\mathbf{y}^{W}$. In the first round these final demands are produced themselves. For the direct inputs, the input matrices are obtained from the IRIOT. For example, we have $\mathbf{A}^{E W}=\mathbf{Z}^{E W}\left(\hat{\mathbf{x}}^{W}\right)^{-1}$ with its typical element $a_{i j}^{E W}=a_{i j}^{E W} / x_{j}^{W}$ indicating the input from industry $i$ in region $E$ that goes to (and is measured per unit of output of) industry $j$ in region $W$. The direct regional inputs amount to $\mathbf{A}^{E E} \mathbf{y}^{E}+\mathbf{A}^{E W} \mathbf{y}^{W}$ in region $E$ and to $\mathbf{A}^{W E} \mathbf{y}^{E}+\mathbf{A}^{W W} \mathbf{y}^{W}$ in region $W$.

To calculate the direct (imported) inputs from country $R$, we would need to have the input coefficients $a_{i j}^{R E}$ and $a_{i j}^{R W}$. Because they are not available, they need to be estimated from the information given in Figures 1 and 2. From the WIOT, we know the value of $a_{i j}^{R T}$. By definition, this should be equal to $\left(z_{i j}^{R E}+z_{i j}^{R W}\right) /\left(x_{j}^{E}+x_{j}^{W}\right)$. Since information for $z_{i j}^{R E}$ and $z_{i j}^{R W}$ is lacking, we first estimate their sum by

$$
\tilde{z}_{i j}^{R E}+\tilde{z}_{i j}^{R W}=a_{i j}^{R T}\left(x_{j}^{E}+x_{j}^{W}\right)
$$


Next we will use the average import shares that are obtained from information that is not listed in the Brazilian IRIOT. That is, for region $E$ it is known for each product $i$ (i.e. the typical product or service produced by industries $i$ ) how much is imported from country $R$ and how much from country $S$ ). The same applies to the imports by region $W$. Note that no information is available with respect to the distribution over the (intermediate and final) users in the importing region. Let the vector $\lambda^{R E}$ denote the vector of import shares, the elements of which are defined as follows

$$
\lambda_{i}^{R E}=\frac{\text { total imports of product } i \text { by region } E \text { from country } R}{\text { total imports of product } i \text { (by regions } E \text { and } W \text { ) from country } R}
$$

A similar definition holds for $\lambda_{i}^{R W}$ and we have that $\lambda_{i}^{R E}+\lambda_{i}^{R W}=1$. The shares for the imports from country $S$ are defined similarly and add to one again (i.e. $\lambda_{i}^{S E}+\lambda_{i}^{S W}=1$ ). We assume that these average import shares apply to each industry $j$ of destination. That is,

$$
\tilde{z}_{i j}^{R E}=\lambda_{i}^{R E}\left(\tilde{z}_{i j}^{R E}+\tilde{z}_{i j}^{R W}\right)=\lambda_{i}^{R E} a_{i j}^{R T}\left(x_{j}^{E}+x_{j}^{W}\right) \text {. }
$$

Finally, let the vector $\boldsymbol{\mu}^{E}$ denote the vector of output shares in region $E$ with its elements defined as

$$
\mu_{i}^{E}=x_{i}^{E} /\left(x_{i}^{E}+x_{i}^{W}\right)
$$

and a similar definition for the output shares of region $W$. This yields for the estimated input coefficients

$$
\tilde{a}_{i j}^{R E}=\frac{\tilde{z}_{i j}^{R E}}{x_{j}^{E}}=\frac{\lambda_{i}^{R E} a_{i j}^{R T}\left(x_{j}^{E}+x_{j}^{W}\right)}{x_{j}^{E}}=\frac{\lambda_{i}^{R E} a_{i j}^{R T}}{\mu_{j}^{E}}
$$

In matrix notation we have $\widetilde{\mathbf{A}}^{R E}=\hat{\boldsymbol{\lambda}}^{R E} \mathbf{A}^{R T}\left(\widehat{\boldsymbol{\mu}}^{E}\right)^{-1}$ for region $E$ and, similarly, for region $W$ we have $\widetilde{\mathbf{A}}^{R W}=\hat{\boldsymbol{\lambda}}^{R W} \mathbf{A}^{R T}\left(\widehat{\boldsymbol{\mu}}^{W}\right)^{-1}$.

The direct inputs in country $R$ necessary to satisfy the final demand vectors $\mathbf{y}^{E}$ and $\mathbf{y}^{W}$ are then given by $\widetilde{\mathbf{A}}^{R E} \mathbf{y}^{E}+\widetilde{\mathbf{A}}^{R W} \mathbf{y}^{W}$. Those in country $S$ are given by $\widetilde{\mathbf{A}}^{S E} \mathbf{y}^{E}+\widetilde{\mathbf{A}}^{S W} \mathbf{y}^{W}$. Together with the regional direct inputs, this yields

$$
\left[\begin{array}{cc}
\widetilde{\mathbf{A}}^{R E} & \widetilde{\mathbf{A}}^{R W} \\
\widetilde{\mathbf{A}}^{S E} & \widetilde{\mathbf{A}}^{S W} \\
\mathbf{A}^{E E} & \mathbf{A}^{E W} \\
\mathbf{A}^{W E} & \mathbf{A}^{W W}
\end{array}\right]\left(\begin{array}{c}
\mathbf{y}^{E} \\
\mathbf{y}^{W}
\end{array}\right)=\left[\begin{array}{cc}
\hat{\boldsymbol{\lambda}}^{R E} \mathbf{A}^{R E}\left(\widehat{\boldsymbol{\mu}}^{E}\right)^{-1} & \hat{\boldsymbol{\lambda}}^{R W} \mathbf{A}^{R W}\left(\widehat{\boldsymbol{\mu}}^{W}\right)^{-1} \\
\hat{\boldsymbol{\lambda}}^{S E} \mathbf{A}^{S E}\left(\widehat{\boldsymbol{\mu}}^{E}\right)^{-1} & \hat{\boldsymbol{\lambda}}^{S W} \mathbf{A}^{S W}\left(\widehat{\boldsymbol{\mu}}^{W}\right)^{-1} \\
\mathbf{A}^{E E} & \mathbf{A}^{E W} \\
\mathbf{A}^{W E} & \mathbf{A}^{W W}
\end{array}\right]\left(\begin{array}{c}
\mathbf{y}^{E} \\
\mathbf{y}^{W}
\end{array}\right)
$$

Finally, combining equations (1) and (2) gives us the direct inputs (in countries $R$ and $S$, and regions $E$ and $W$ ) that are necessary for an arbitrary final demand vector. They are given by

$$
\left[\begin{array}{cccc}
\mathbf{A}^{R R} & \mathbf{A}^{R S} & \widetilde{\mathbf{A}}^{R E} & \widetilde{\mathbf{A}}^{R W} \\
\mathbf{A}^{S R} & \mathbf{A}^{S S} & \widetilde{\mathbf{A}}^{S E} & \widetilde{\mathbf{A}}^{S W} \\
\widetilde{\mathbf{A}}^{E R} & \widetilde{\mathbf{A}}^{E S} & \mathbf{A}^{E E} & \mathbf{A}^{E W} \\
\widetilde{\mathbf{A}}^{W R} & \widetilde{\mathbf{A}}^{W S} & \mathbf{A}^{W E} & \mathbf{A}^{W W}
\end{array}\right]\left(\begin{array}{c}
\mathbf{y}^{R} \\
\mathbf{y}^{S} \\
\mathbf{y}^{E} \\
\mathbf{y}^{W}
\end{array}\right)=
$$




$$
=\left[\begin{array}{cccc}
\mathbf{A}^{R R} & \mathbf{A}^{R S} & \hat{\boldsymbol{\lambda}}^{R E} \mathbf{A}^{R E}\left(\widehat{\boldsymbol{\mu}}^{E}\right)^{-1} & \hat{\boldsymbol{\lambda}}^{R W} \mathbf{A}^{R W}\left(\widehat{\boldsymbol{\mu}}^{W}\right)^{-1} \\
\mathbf{A}^{S R} & \mathbf{A}^{S S} & \hat{\boldsymbol{\lambda}}^{S E} \mathbf{A}^{S E}\left(\widehat{\boldsymbol{\mu}}^{E}\right)^{-1} & \hat{\boldsymbol{\lambda}}^{S W} \mathbf{A}^{S W}\left(\widehat{\boldsymbol{\mu}}^{W}\right)^{-1} \\
\widehat{\boldsymbol{\sigma}}^{E R} \mathbf{A}^{T R} & \widehat{\boldsymbol{\sigma}}^{E S} \mathbf{A}^{T S} & \mathbf{A}^{E E} & \mathbf{A}^{E W} \\
\widehat{\boldsymbol{\sigma}}^{W R} \mathbf{A}^{T R} & \widehat{\boldsymbol{\sigma}}^{W S} \mathbf{A}^{T S} & \mathbf{A}^{W E} & \mathbf{A}^{W W}
\end{array}\right]\left(\begin{array}{c}
\mathbf{y}^{R} \\
\mathbf{y}^{S} \\
\mathbf{y}^{E} \\
\mathbf{y}^{W}
\end{array}\right)
$$

Let us write these direct inputs in condensed form as Ay. The production of the direct inputs requires further inputs to the amount of $\mathbf{A}^{2} \mathbf{y}$, and so forth. Together with the initial outputs $(\mathbf{y})$, this yields $\left(\mathbf{I}+\mathbf{A}+\mathbf{A}^{\mathbf{2}}+\cdots\right) \mathbf{y}=(\mathbf{I}-\mathbf{A})^{-1} \mathbf{y}=\mathbf{L y}$, where $\mathbf{L}$ denotes the Leontief inverse which can be partitioned in the same way as $\mathbf{A}$.

In our application, we are not so much interested in the output levels (necessary for an arbitrary final demand vector) but in the value added. Define the value added coefficients for country $R$ as $g_{i}^{R}=v_{i}^{R} / x_{i}^{R}$, indicating the value added per unit of output. In matrix notation this becomes $\left(\mathbf{g}^{R}\right)^{\prime}=\left(\mathbf{v}^{R}\right)^{\prime}\left(\hat{\mathbf{x}}^{R}\right)^{-1}$. The total values added created in country $R$, in country $S$, in region $E$, and in region $W$, necessary for the final demand vector $\mathbf{y}$ are given by the four elements of the vector

$$
\left[\begin{array}{cccc}
\left(\mathbf{g}^{R}\right)^{\prime} & 0 & 0 & 0 \\
0 & \left(\mathbf{g}^{S}\right)^{\prime} & 0 & 0 \\
0 & 0 & \left(\mathbf{g}^{E}\right)^{\prime} & 0 \\
0 & 0 & 0 & \left(\mathbf{g}^{W}\right)^{\prime}
\end{array}\right]\left[\begin{array}{cccc}
\mathbf{L}^{R R} & \mathbf{L}^{R S} & \mathbf{L}^{R E} & \mathbf{L}^{R W} \\
\mathbf{L}^{S R} & \mathbf{L}^{S S} & \mathbf{L}^{S E} & \mathbf{L}^{S W} \\
\mathbf{L}^{E R} & \mathbf{L}^{E S} & \mathbf{L}^{E E} & \mathbf{L}^{E W} \\
\mathbf{L}^{W R} & \mathbf{L}^{W S} & \mathbf{L}^{W E} & \mathbf{L}^{W W}
\end{array}\right]\left(\begin{array}{c}
\mathbf{y}^{R} \\
\mathbf{y}^{S} \\
\mathbf{y}^{E} \\
\mathbf{y}^{W}
\end{array}\right)
$$

The central question in our application is how much value added that is generated in region $E$ (or $W$ ) is contained in the final use of, for example, country $R$ ? This is the export of value added from region $E$ (or $W$ ) to country $R$. We apply equation (4) and now take the final demand vector of country $R$ instead of an arbitrary final demand vector. Final users in country $R$ demand $\mathbf{c}^{R R}$ of domestically produced goods and services, import $\mathbf{c}^{S R}$ from country $S$, and $\mathbf{c}^{T R}$ from country $T$. Like we did with the input matrices, we use the export shares of regions $E$ and $W$ to split $\mathbf{c}^{T R}$. That is, $\widehat{\boldsymbol{\sigma}}^{E R} \mathbf{c}^{T R}$ gives the exports from region $E$ to final users in country $R$ and $\widehat{\boldsymbol{\sigma}}^{W R} \mathbf{c}^{T R}$ gives the exports from region $W$. This yields

$$
\left[\begin{array}{cccc}
\left(\mathbf{g}^{R}\right)^{\prime} & 0 & 0 & 0 \\
0 & \left(\mathbf{g}^{S}\right)^{\prime} & 0 & 0 \\
0 & 0 & \left(\mathbf{g}^{E}\right)^{\prime} & 0 \\
0 & 0 & 0 & \left(\mathbf{g}^{W}\right)^{\prime}
\end{array}\right]\left[\begin{array}{cccc}
\mathbf{L}^{R R} & \mathbf{L}^{R S} & \mathbf{L}^{R E} & \mathbf{L}^{R W} \\
\mathbf{L}^{S R} & \mathbf{L}^{S S} & \mathbf{L}^{S E} & \mathbf{L}^{S W} \\
\mathbf{L}^{E R} & \mathbf{L}^{E S} & \mathbf{L}^{E E} & \mathbf{L}^{E W} \\
\mathbf{L}^{W R} & \mathbf{L}^{W S} & \mathbf{L}^{W E} & \mathbf{L}^{W W}
\end{array}\right]\left(\begin{array}{c}
\mathbf{c}^{R R} \\
\mathbf{c}^{S R} \\
\widehat{\boldsymbol{\sigma}}^{E R} \mathbf{c}^{T R} \\
\hat{\boldsymbol{\sigma}}^{W R} \mathbf{c}^{T R}
\end{array}\right)
$$

The third element of this vector gives the value added of region $E$ that is embodied in the final use of country $R$ and the fourth element gives the final demand of region $W$.

In the same fashion are we also interested in the value added generated in country $R$ that is imported by region $E$. That is, in answering the question how much of country $R$ 's value added is embodied in the final use of region $E$. The final demand for goods and services produced in the own region are given by $\mathbf{c}^{E E}$, for imports from region $W$ by $\mathbf{c}^{W E}$. The imports by region $E$ 's final users of products from country $R$ are unknown. Like we did with the input matrices for the imports, the imports for final use in region $E$ are estimated using import shares which yields $\hat{\lambda}^{R E} \mathbf{c}^{R T}$. The same procedure is followed for the imports by final users from country $S$. This yields 


$$
\left[\begin{array}{cccc}
\left(\mathbf{g}^{R}\right)^{\prime} & 0 & 0 & 0 \\
0 & \left(\mathbf{g}^{S}\right)^{\prime} & 0 & 0 \\
0 & 0 & \left(\mathbf{g}^{E}\right)^{\prime} & 0 \\
0 & 0 & 0 & \left(\mathbf{g}^{W}\right)^{\prime}
\end{array}\right]\left[\begin{array}{cccc}
\mathbf{L}^{R R} & \mathbf{L}^{R S} & \mathbf{L}^{R E} & \mathbf{L}^{R W} \\
\mathbf{L}^{S R} & \mathbf{L}^{S S} & \mathbf{L}^{S E} & \mathbf{L}^{S W} \\
\mathbf{L}^{E R} & \mathbf{L}^{E S} & \mathbf{L}^{E E} & \mathbf{L}^{E W} \\
\mathbf{L}^{W R} & \mathbf{L}^{W S} & \mathbf{L}^{W E} & \mathbf{L}^{W W}
\end{array}\right]\left(\begin{array}{c}
\hat{\boldsymbol{\lambda}}^{R E} \mathbf{c}^{R T} \\
\hat{\boldsymbol{\lambda}}^{S E} \mathbf{c}^{S T} \\
\mathbf{c}^{E E} \\
\mathbf{c}^{W E}
\end{array}\right)
$$

The first element of this vector gives the value added generated in country $R$ that is embodied in the final use in region $E$ and the second element gives the import of value added of country $S$ by final users in region $E$.

\section{Results}

In this section, we present some results from the empirical application. ${ }^{7}$ Focusing its central question, we intend to analyze the Brazilian states' trade in value added, among them and the rest of the world. In order to contextualize them, these results are compared to those obtained for the countries in the WIOT. Finally, the Brazilian states' trade in value added with China and USA - the top trade partners of Brazil in 2008 - is analyzed, better illustrating the detailed results that our approach can provide.

\subsection{Brazilian states' trade in value added}

The results for international trade in value added of the Brazilian states - aggregated by all source / destination industries and countries, so that we can focus attention on the states - are presented in Table 1.

The first data column shows the total value added generated in the state that is embodied in the final use of other countries. The following column indicates the ratio between the exports in value added and the total value added generated in the state. The third column shows the total value added generated in other countries that is embodied in the final use of the state. The following column indicates the ratio between the imports in value added and the total value added generated in the state. The fifth column shows the surplus (exports less imports) of trade in value added of the state. The last column indicates the ratio between the surplus in value added and the total value added generated in the state.

Mato Grosso, for example, exported US\$ 5471 million of value added in 2008 - that is, US\$ 5471 million in value added generated in this state was embodied in the final use of other countries. On the other hand, imports of value added of Mato Grosso corresponded to US\$ 1568 million - in other words, final use of Mato Grosso embodied US\$ 1568 million in value added generated in other countries. So, in 2008, Mato Grosso presented a positive surplus of international trade in value added of US\$ 3903 million, amounting in $15.5 \%$ of total value added generated in the state in that year.

Regarding the surplus of international trade in value added, we can observe that, in 2008. Amazonas presented the largest shortage, as its imports of value added greatly surpassed its exports. In contrast, Minas Gerais presented the largest positive surplus among all the Brazilian states, but it corresponded to only $4.1 \%$ of the total value added generated in the state in 2008. Relatively to that ratio, Pará stands out: its surplus of international trade amounted in $17.2 \%$ of total value added generated in the state in 2008. Also Mato Grosso stands out presenting net exports with a surplus larger than $10 \%$ of the states' value added $(15.5 \%$ in fact).

\footnotetext{
${ }^{7}$ For detailed results (by region, by country, and by industry), please contact the authors.
} 
Table 1 - International trade in value added, Brazilian states, 2008 - million US\$

\begin{tabular}{|c|c|c|c|c|c|c|}
\hline & Exports & $\begin{array}{c}\% \text { Value } \\
\text { Added }\end{array}$ & Imports & $\begin{array}{c}\% \text { Value } \\
\text { Added }\end{array}$ & Surplus & $\begin{array}{c}\% \text { Value } \\
\text { Added }\end{array}$ \\
\hline Acre & 137 & $4.1 \%$ & 230 & $6.8 \%$ & -92 & $-2.8 \%$ \\
\hline Amapá & 182 & $5.3 \%$ & 312 & $9.2 \%$ & -130 & $-3.8 \%$ \\
\hline Amazonas & 1,607 & $7.8 \%$ & 6,205 & $30.0 \%$ & $-4,599$ & $-22.3 \%$ \\
\hline Pará & 7,964 & $27.2 \%$ & 2,934 & $10.0 \%$ & 5,029 & $17.2 \%$ \\
\hline Rondônia & 634 & $7.4 \%$ & 773 & $9.0 \%$ & -139 & $-1.6 \%$ \\
\hline Roraima & 60 & $2.4 \%$ & 142 & $5.8 \%$ & -83 & $-3.4 \%$ \\
\hline Tocantins & 422 & $6.6 \%$ & 549 & $8.6 \%$ & -127 & $-2.0 \%$ \\
\hline Alagoas & 769 & $8.1 \%$ & 734 & $7.8 \%$ & 34 & $0.4 \%$ \\
\hline Bahia & 6,736 & $11.8 \%$ & 7,737 & $13.6 \%$ & $-1,002$ & $-1.8 \%$ \\
\hline Ceará & 1,522 & $5.4 \%$ & 2,870 & $10.1 \%$ & $-1,348$ & $-4.8 \%$ \\
\hline Maranhão & 2,322 & $12.2 \%$ & 2,802 & $14.7 \%$ & -480 & $-2.5 \%$ \\
\hline Paraíba & 352 & $2.8 \%$ & 1,365 & $11.0 \%$ & $-1,013$ & $-8.2 \%$ \\
\hline Pernambuco & 1,495 & $4.6 \%$ & 4,144 & $12.7 \%$ & $-2,650$ & $-8.1 \%$ \\
\hline Piauí & 303 & $3.8 \%$ & 864 & $10.8 \%$ & -561 & $-7.0 \%$ \\
\hline Sergipe & 627 & $6.6 \%$ & 787 & $8.3 \%$ & -159 & $-1.7 \%$ \\
\hline Rio Grande do Norte & 720 & $6.0 \%$ & 1,101 & $9.2 \%$ & -381 & $-3.2 \%$ \\
\hline Distrito Federal & 868 & $1.5 \%$ & 4,391 & $7.8 \%$ & $-3,523$ & $-6.3 \%$ \\
\hline Goiás & 3,358 & $9.5 \%$ & 4,067 & $11.5 \%$ & -709 & $-2.0 \%$ \\
\hline Mato Grosso & 5,471 & $21.7 \%$ & 1,568 & $6.2 \%$ & 3,903 & $15.5 \%$ \\
\hline Mato Grosso do Sul & 1,702 & $11.3 \%$ & 1,839 & $12.2 \%$ & -136 & $-0.9 \%$ \\
\hline Espírito Santo & 6,391 & $22.0 \%$ & 5,229 & $18.0 \%$ & 1,161 & $4.0 \%$ \\
\hline Minas Gerais & 19,149 & $14.6 \%$ & 13,805 & $10.5 \%$ & 5,343 & $4.1 \%$ \\
\hline Rio de Janeiro & 19,835 & $12.6 \%$ & 17,352 & $11.0 \%$ & 2,482 & $1.6 \%$ \\
\hline São Paulo & 57,476 & $12.7 \%$ & 57,765 & $12.7 \%$ & -289 & $-0.1 \%$ \\
\hline Paraná & 10,952 & $13.1 \%$ & 11,324 & $13.5 \%$ & -372 & $-0.4 \%$ \\
\hline Santa Catarina & 6,699 & $11.6 \%$ & 7,672 & $13.2 \%$ & -973 & $-1.7 \%$ \\
\hline Rio Grande do Sul & 13,304 & $14.2 \%$ & 12,293 & $13.1 \%$ & 1,011 & $1.1 \%$ \\
\hline Total & 171,056 & & 170,859 & & 197 & \\
\hline Average weighted & & $12.2 \%$ & & $12.2 \%$ & & $0.0 \%$ \\
\hline Average unweighted & & $9.9 \%$ & & $11.4 \%$ & & $-1.5 \%$ \\
\hline
\end{tabular}

At national level, as can be seem in the bottom of Table 1, turns out that the exports of value added (US\$ 171056 million) were very close to the imports of value added (US\$ 170859 million), resulting in a positive but small surplus of international trade in value added.

The bottom two rows of Table 1 disclose an important point regarding the Brazilian states' trade in value added. Both the exports and imports ratios to value added present higher weighted average across the Brazilian states (where the weights are the total value added generated in each state) than simple average. This fact indicates that states with higher value added export a larger share of their value added. In the same fashion, states with higher value added import products and services that amounts in a larger share of their value added.

Concerning the Brazilian macroregions, Table 1 shows that trade in value added is highly concentrated in the states of Southeast and South. In 2008, these states responded for $78 \%$ of exported value added and for $73 \%$ of imported value added in Brazil. São Paulo alone accounted for $34 \%$ of both exported and imported value added in the country.

How do the results for Brazil and its states relate to other countries? In order to contextualize them, we present Table 2, which is equivalent to Table 1 but was computed for selected countries - those with the highest values of trade in value added and other developing countries - and for the WIOT as a whole. 
Table 2 - Trade in value added, selected countries and total, 2008 - million US\$

\begin{tabular}{|c|c|c|c|c|c|c|}
\hline & Exports & $\begin{array}{c}\% \text { Value } \\
\text { Added }\end{array}$ & Imports & $\begin{array}{c}\% \text { Value } \\
\text { Added }\end{array}$ & Surplus & $\begin{array}{c}\% \text { Value } \\
\text { Added }\end{array}$ \\
\hline Canada & 372,396 & $26.5 \%$ & 329,022 & $23.4 \%$ & 43,373 & $3.1 \%$ \\
\hline China & $1,525,398$ & $34.6 \%$ & 896,192 & $20.3 \%$ & 629,206 & $14.3 \%$ \\
\hline Germany & $1,049,941$ & $32.1 \%$ & 758,659 & $23.2 \%$ & 291,281 & $8.9 \%$ \\
\hline France & 449,716 & $17.6 \%$ & 501,144 & $19.6 \%$ & $-51,428$ & $-2.0 \%$ \\
\hline UK & 540,362 & $22.1 \%$ & 551,867 & $22.5 \%$ & $-11,505$ & $-0.5 \%$ \\
\hline Indonesia & 117,124 & $24.1 \%$ & 100,465 & $20.7 \%$ & 16,659 & $3.4 \%$ \\
\hline India & 183,084 & $15.4 \%$ & 217,587 & $18.3 \%$ & $-34,504$ & $-2.9 \%$ \\
\hline Japan & 676,130 & $14.2 \%$ & 596,165 & $12.5 \%$ & 79,966 & $1.7 \%$ \\
\hline Korea & 246,761 & $29.7 \%$ & 247,194 & $29.7 \%$ & -433 & $-0.1 \%$ \\
\hline Mexico & 190,185 & $18.4 \%$ & 188,421 & $18.2 \%$ & 1,764 & $0.2 \%$ \\
\hline Netherlands & 290,840 & $37.5 \%$ & 222,624 & $28.7 \%$ & 68,216 & $8.8 \%$ \\
\hline Russia & 355,670 & $26.0 \%$ & 262,694 & $19.2 \%$ & 92,976 & $6.8 \%$ \\
\hline USA & $1,302,756$ & $9.0 \%$ & $1,891,039$ & $13.1 \%$ & $-588,283$ & $-4.1 \%$ \\
\hline RoW & $2,172,022$ & $27.2 \%$ & $2,564,064$ & $32.1 \%$ & $-392,042$ & $-4.9 \%$ \\
\hline Total & $11,787,589$ & & $11,787,786$ & & -197 & \\
\hline Average weighted & & $20.9 \%$ & & $20.9 \%$ & & $0.0 \%$ \\
\hline Average unweighted & & $28.7 \%$ & & $29.7 \%$ & & $-1.1 \%$ \\
\hline
\end{tabular}

From Table 2, we can observe that the average country is much more involved in the global value chain than Brazil is. The second to last row indicates that the average country presents approximately twice as much trade in value added, as \% of country's value added. Still paying attention to the bottom rows of Table 2, it is interesting that both the exports and imports ratios to value added present higher simple average across the countries than weighted average - the opposite to what was observed for the Brazilian states. In other words, we can point out that in average, countries with little value added (i.e. small countries) export a larger share of their value added than countries with higher value added (i.e. large countries). The same conclusion holds for the imports. The most illustrative country to this point is, in Table 2, the Netherlands. Among others, we can point out as distinguished small, open countries in the WIOT, omitted in the Table: Luxembourg (which exports of value added amounted in $61.4 \%$ of total value added of the country) and Bulgaria (which imports of value added amount in $57.5 \%$ of its total value added).

Observing the results for each country, we can point out that the surplus of trade in value added close to zero presented by Brazil is a special case among the countries in the WIOT. Besides Brazil, only UK, Korea, Mexico, and Slovakia (omitted in Table 2) presented, in 2008, a ratio between surplus of trade in value added and total value added in the interval [$0.01,0.01]$. Perhaps the country with the greatest resemblance to Brazil concerning trade in value added is Mexico, which also showed a positive and small surplus of trade in value added. However, both Mexican exports and imports of value added are higher than those of Brazil and its total value added is smaller, what emphasizes the little engagement of Brazil in the global value chain.

China stands out in Table 2, presenting the highest positive surplus of trade in value added among all the countries in the WIOT. In 2008, that Chinese surplus amounted in $14.3 \%$ of the total value added in the country. On the other hand, there is the case of USA - in 2008, according to Table 2, the country's large shortage corresponded to $4.1 \%$ of its total value added. The relationship of the Brazilian states with these two countries will be further investigated below. 


\subsection{The Brazilian value chain}

We have observed that Brazilian trade in value added is somewhat limited. So, it is interesting to more carefully analyze the trade of Brazilian states. Do they trade? And, if yes, with whom? Table 3 aims to add to this question, showing the composition of trade in value added of the Brazilian states, as in 2008.

Table 3 - Domestic and regional shares in total trade in value added, Brazilian states, 2008

\begin{tabular}{|c|c|c|c|c|c|}
\hline & Domestic & $\begin{array}{c}\text { Regional } \\
\text { exports }\end{array}$ & $\begin{array}{l}\text { Regional } \\
\text { imports }\end{array}$ & $\begin{array}{c}\text { Regional } \\
\text { Surplus }\end{array}$ & $\begin{array}{c}\text { Intnl } \\
\text { Surplus }\end{array}$ \\
\hline Acre & $73 \%$ & $22.5 \%$ & $34.4 \%$ & $-12 \%$ & $-3 \%$ \\
\hline Amapá & $82 \%$ & $12.6 \%$ & $42.4 \%$ & $-30 \%$ & $-4 \%$ \\
\hline Amazonas & $41 \%$ & $51.0 \%$ & $30.7 \%$ & $20 \%$ & $-22 \%$ \\
\hline Pará & $57 \%$ & $16.2 \%$ & $44.2 \%$ & $-28 \%$ & $17 \%$ \\
\hline Rondônia & $68 \%$ & $25.1 \%$ & $42.4 \%$ & $-17 \%$ & $-2 \%$ \\
\hline Roraima & $84 \%$ & $13.9 \%$ & $24.0 \%$ & $-10 \%$ & $-3 \%$ \\
\hline Tocantins & $64 \%$ & $29.6 \%$ & $37.9 \%$ & $-8 \%$ & $-2 \%$ \\
\hline Alagoas & $69 \%$ & $22.5 \%$ & $35.2 \%$ & $-13 \%$ & $0 \%$ \\
\hline Bahia & $68 \%$ & $19.9 \%$ & $40.4 \%$ & $-21 \%$ & $-2 \%$ \\
\hline Ceará & $68 \%$ & $26.8 \%$ & $30.8 \%$ & $-4 \%$ & $-5 \%$ \\
\hline Maranhão & $62 \%$ & $25.5 \%$ & $38.3 \%$ & $-13 \%$ & $-3 \%$ \\
\hline Paraíba & $80 \%$ & $16.8 \%$ & $47.2 \%$ & $-30 \%$ & $-8 \%$ \\
\hline Pernambuco & $76 \%$ & $19.8 \%$ & $39.0 \%$ & $-19 \%$ & $-8 \%$ \\
\hline Piauí & $81 \%$ & $15.3 \%$ & $60.2 \%$ & $-45 \%$ & $-7 \%$ \\
\hline Sergipe & $63 \%$ & $30.8 \%$ & $36.8 \%$ & $-6 \%$ & $-2 \%$ \\
\hline Rio Grande do Norte & $72 \%$ & $22.0 \%$ & $39.6 \%$ & $-18 \%$ & $-3 \%$ \\
\hline Distrito Federal & $88 \%$ & $10.1 \%$ & $31.4 \%$ & $-21 \%$ & $-6 \%$ \\
\hline Goiás & $63 \%$ & $27.4 \%$ & $34.5 \%$ & $-7 \%$ & $-2 \%$ \\
\hline Mato Grosso & $44 \%$ & $34.2 \%$ & $23.8 \%$ & $10 \%$ & $15 \%$ \\
\hline Mato Grosso do Sul & $61 \%$ & $28.1 \%$ & $36.4 \%$ & $-8 \%$ & $-1 \%$ \\
\hline Espírito Santo & $48 \%$ & $30.5 \%$ & $34.5 \%$ & $-4 \%$ & $4 \%$ \\
\hline Minas Gerais & $61 \%$ & $24.3 \%$ & $32.6 \%$ & $-8 \%$ & $4 \%$ \\
\hline Rio de Janeiro & $64 \%$ & $23.4 \%$ & $30.8 \%$ & $-7 \%$ & $2 \%$ \\
\hline São Paulo & $57 \%$ & $30.5 \%$ & $14.1 \%$ & $16 \%$ & $0 \%$ \\
\hline Paraná & $54 \%$ & $32.4 \%$ & $26.7 \%$ & $6 \%$ & $0 \%$ \\
\hline Santa Catarina & $57 \%$ & $31.4 \%$ & $30.2 \%$ & $1 \%$ & $-2 \%$ \\
\hline Rio Grande do Sul & $61 \%$ & $25.1 \%$ & $27.8 \%$ & $-3 \%$ & $1 \%$ \\
\hline
\end{tabular}

For example, according to Table 3, in 2008, 54\% of Paraná's value added was generated for its own final use (domestic share), $32 \%$ for rest of Brazil's final use (regional exports' share), and - found by difference $-13 \%$ for other countries' final use. Moreover, Paraná's final use led to purchases in value added from other Brazilian states amounted in $27 \%$ of its own total value added (regional imports' share). As a result, Paraná's regional trade presented a positive surplus corresponding to $6 \%$ of its value added

Regarding the domestic share of the responsibility for value added generated in the Brazilian states, a first note is that in general it is somewhat smaller than for countries in the WIOT (81.3\% in average). That share is notably small in Amazonas: only $41 \%$ of its value added was due to its own final use. In the other hand, Distrito Federal's final use was greatly responsible for its own value added $(88 \%)$. 
The note that the domestic shares presented in Table 3 are smaller than those for countries is fairly expected, since states might trade with each other inside a country. We can point out that this is the case for Brazilian states: the average regional exports' share was $24.7 \%$, in 2008. Amazonas is especially outstanding, as approximately half of its value added was due to the final use of other states in the country. Besides, the average regional imports' share was $35.1 \%$ - reaching the level of $60 \%$ in Piauí. Therefore, it is possible to answer the question motivating Table 3: yes, Brazilian states do trade, and mainly with each other.

The two final columns in Table 3 present the surplus of each state from regional and international trade in value added. From them, it is remarkable that 16 out of 27 states had 'two shortages' in 2008, and Mato Grosso was the only state with 'two surpluses'.

Concerning the regional trade in value added, since by definition there is balance in the national level, we observe that the surplus of $16 \%$ for São Paulo 'does the job'. The total of regional surpluses in 2008 was US\$ 86667 million, of which São Paulo was responsible for $85.8 \%$. This fact indicates that there were net imports by other states from São Paulo, what can be observed in Table 4, which is analogous to Table 1 but considers Brazilian states' direct and indirect trade in value added with São Paulo.

Table 4 - Trade in value added with São Paulo, Brazilian states, 2008 - million US\$

\begin{tabular}{|c|c|c|c|c|c|c|}
\hline & Exports & $\begin{array}{c}\% \text { Value } \\
\text { Added }\end{array}$ & Imports & $\begin{array}{c}\% \text { Value } \\
\text { Added }\end{array}$ & Surplus & $\begin{array}{c}\% \text { Value } \\
\text { Added }\end{array}$ \\
\hline Acre & 151 & $4.5 \%$ & 437 & $13.0 \%$ & -285 & $-8.5 \%$ \\
\hline Amapá & 80 & $2.4 \%$ & 585 & $17.2 \%$ & -505 & $-14.9 \%$ \\
\hline Amazonas & 3,722 & $18.0 \%$ & 2,928 & $14.2 \%$ & 794 & $3.8 \%$ \\
\hline Pará & 1,049 & $3.6 \%$ & 4,941 & $16.9 \%$ & $-3,892$ & $-13.3 \%$ \\
\hline Rondônia & 506 & $5.9 \%$ & 1,528 & $17.8 \%$ & $-1,022$ & $-11.9 \%$ \\
\hline Roraima & 73 & $3.0 \%$ & 233 & $9.5 \%$ & -160 & $-6.5 \%$ \\
\hline Tocantins & 333 & $5.2 \%$ & 952 & $14.9 \%$ & -619 & $-9.7 \%$ \\
\hline Alagoas & 454 & $4.8 \%$ & 1,228 & $13.0 \%$ & -774 & $-8.2 \%$ \\
\hline Bahia & 3,720 & $6.5 \%$ & 10,235 & $17.9 \%$ & $-6,516$ & $-11.4 \%$ \\
\hline Ceará & 1,583 & $5.6 \%$ & 2,951 & $10.4 \%$ & $-1,368$ & $-4.8 \%$ \\
\hline Maranhão & 1,084 & $5.7 \%$ & 2,633 & $13.8 \%$ & $-1,549$ & $-8.1 \%$ \\
\hline Paraíba & 458 & $3.7 \%$ & 2,066 & $16.7 \%$ & $-1,609$ & $-13.0 \%$ \\
\hline Pernambuco & 1,418 & $4.4 \%$ & 4,860 & $14.9 \%$ & $-3,442$ & $-10.6 \%$ \\
\hline Piauí & 241 & $3.0 \%$ & 1,720 & $21.5 \%$ & $-1,479$ & $-18.5 \%$ \\
\hline Sergipe & 657 & $6.9 \%$ & 1,229 & $12.9 \%$ & -572 & $-6.0 \%$ \\
\hline Rio Grande do Norte & 732 & $6.1 \%$ & 1,661 & $13.8 \%$ & -929 & $-7.7 \%$ \\
\hline Distrito Federal & 594 & $1.1 \%$ & 7,795 & $13.9 \%$ & $-7,201$ & $-12.8 \%$ \\
\hline Goiás & 2,580 & $7.3 \%$ & 5,541 & $15.7 \%$ & $-2,960$ & $-8.4 \%$ \\
\hline Mato Grosso & 1,869 & $7.4 \%$ & 2,626 & $10.4 \%$ & -758 & $-3.0 \%$ \\
\hline Mato Grosso do Sul & 1,328 & $8.8 \%$ & 2,461 & $16.4 \%$ & $-1,133$ & $-7.5 \%$ \\
\hline Espírito Santo & 2,561 & $8.8 \%$ & 3,989 & $13.7 \%$ & $-1,428$ & $-4.9 \%$ \\
\hline Minas Gerais & 10,333 & $7.9 \%$ & 21,689 & $16.6 \%$ & $-11,356$ & $-8.7 \%$ \\
\hline Rio de Janeiro & 10,080 & $6.4 \%$ & 24,136 & $15.3 \%$ & $-14,055$ & $-8.9 \%$ \\
\hline Paraná & 7,578 & $9.0 \%$ & 10,312 & $12.3 \%$ & $-2,734$ & $-3.3 \%$ \\
\hline Santa Catarina & 4,409 & $7.6 \%$ & 7,736 & $13.4 \%$ & $-3,327$ & $-5.7 \%$ \\
\hline Rio Grande do Sul & 6,460 & $6.9 \%$ & 11,966 & $12.8 \%$ & $-5,506$ & $-5.9 \%$ \\
\hline Total & 64,051 & & 138,435 & & $-74,384$ & \\
\hline Average weighted & & $6.8 \%$ & & $14.6 \%$ & & $-7.9 \%$ \\
\hline Average unweighted & & $6.2 \%$ & & $14.6 \%$ & & $-8.4 \%$ \\
\hline
\end{tabular}


From Table 4, in 2008 only Amazonas was not a net importer of value added from São Paulo. However, even for Amazonas, São Paulo was the main source (other than the own state) of value added. The relevance of São Paulo for trade in Brazil is reinforced by the fact that it was also the main importer of value added for 25 out of 27 states - the exceptions are Pará and Distrito Federal, which largest share of exports of value added went to USA and Minas Gerais, respectively.

By calculating the ratio between the value added embodied in final use of a state and the value added generated in a state, we obtain what can be called a 'value added footprint'. The results are presented in Table 5.

Table 5 - 'Value added footprints', Brazilian states, 2008

\begin{tabular}{lc}
\hline & $\begin{array}{c}\text { Value added } \\
\text { footprints }\end{array}$ \\
\cline { 2 - 2 } Acre & 1.15 \\
Amapá & 1.34 \\
Amazonas & 1.02 \\
Pará & 1.11 \\
Rondônia & 1.19 \\
Roraima & 1.13 \\
Tocantins & 1.10 \\
Alagoas & 1.12 \\
Bahia & 1.22 \\
Ceará & 1.09 \\
Maranhão & 1.15 \\
Paraíba & 1.39 \\
Pernambuco & 1.27 \\
Piauí & 1.52 \\
Sergipe & 1.08 \\
Rio Grande do Norte & 1.21 \\
Distrito Federal & 1.28 \\
Goiás & 1.09 \\
Mato Grosso & 0.74 \\
Mato Grosso do Sul & 1.09 \\
Espírito Santo & 1.00 \\
Minas Gerais & 1.04 \\
Rio de Janeiro & 1.06 \\
São Paulo & 0.84 \\
Paraná & 0.95 \\
Santa Catarina & 1.00 \\
Rio Grande do Sul & 1.02 \\
\hline &
\end{tabular}

According to Table 5, only Mato Grosso, São Paulo, and Paraná had value added footprints lower than 1 in 2008, i.e., they generated greater amounts of value added than those required by their final use (from them, other states and countries, directly and indirectly). This indicates that those states have important roles in the Brazilian trade as net suppliers of value added.

\subsection{Trade with China and USA}

In order to better illustrate the detail level of our empirical application, we analyze below the trade between the Brazilian states and the two top trade partners of Brazil in 2008, 
China and USA. Some worldwide results for these countries were presented in the previous subsection.

According to Table 2, in 2008 China presented an outstanding positive surplus of trade in value added worldwide. In order to investigate if this is also the case for the Brazilian states' trade relations with the country, Table 6 presents results referring to direct and indirect trade in value added with China.

Table 6 -Trade in value added with China, Brazilian states, 2008 - million US\$

\begin{tabular}{|c|c|c|c|c|c|c|}
\hline & Exports & $\begin{array}{c}\% \text { Value } \\
\text { Added }\end{array}$ & Imports & $\begin{array}{c}\% \text { Value } \\
\text { Added }\end{array}$ & Surplus & $\begin{array}{c}\% \text { Value } \\
\text { Added }\end{array}$ \\
\hline Acre & 12 & $\overline{0.3 \%}$ & 21 & $0.6 \%$ & -9 & $-0.3 \%$ \\
\hline Amapá & 15 & $0.4 \%$ & 32 & $0.9 \%$ & -18 & $-0.5 \%$ \\
\hline Amazonas & 88 & $0.4 \%$ & 1,920 & $9.3 \%$ & $-1,832$ & $-8.9 \%$ \\
\hline Pará & 1,200 & $4.1 \%$ & 275 & $0.9 \%$ & 924 & $3.2 \%$ \\
\hline Rondônia & 39 & $0.5 \%$ & 88 & $1.0 \%$ & -48 & $-0.6 \%$ \\
\hline Roraima & 3 & $0.1 \%$ & 12 & $0.5 \%$ & -9 & $-0.4 \%$ \\
\hline Tocantins & 70 & $1.1 \%$ & 56 & $0.9 \%$ & 14 & $0.2 \%$ \\
\hline Alagoas & 29 & $0.3 \%$ & 75 & $0.8 \%$ & -45 & $-0.5 \%$ \\
\hline Bahia & 465 & $0.8 \%$ & 805 & $1.4 \%$ & -341 & $-0.6 \%$ \\
\hline Ceará & 75 & $0.3 \%$ & 291 & $1.0 \%$ & -216 & $-0.8 \%$ \\
\hline Maranhão & 378 & $2.0 \%$ & 180 & $0.9 \%$ & 199 & $1.0 \%$ \\
\hline Paraíba & 17 & $0.1 \%$ & 193 & $1.6 \%$ & -177 & $-1.4 \%$ \\
\hline Pernambuco & 75 & $0.2 \%$ & 361 & $1.1 \%$ & -285 & $-0.9 \%$ \\
\hline Piauí & 33 & $0.4 \%$ & 84 & $1.0 \%$ & -51 & $-0.6 \%$ \\
\hline Sergipe & 36 & $0.4 \%$ & 74 & $0.8 \%$ & -38 & $-0.4 \%$ \\
\hline Rio Grande do Norte & 32 & $0.3 \%$ & 101 & $0.8 \%$ & -69 & $-0.6 \%$ \\
\hline Distrito Federal & 48 & $0.1 \%$ & 320 & $0.6 \%$ & -273 & $-0.5 \%$ \\
\hline Goiás & 467 & $1.3 \%$ & 349 & $1.0 \%$ & 118 & $0.3 \%$ \\
\hline Mato Grosso & 893 & $3.5 \%$ & 141 & $0.6 \%$ & 752 & $3.0 \%$ \\
\hline Mato Grosso do Sul & 216 & $1.4 \%$ & 185 & $1.2 \%$ & 31 & $0.2 \%$ \\
\hline Espírito Santo & 613 & $2.1 \%$ & 945 & $3.3 \%$ & -332 & $-1.1 \%$ \\
\hline Minas Gerais & 1,266 & $1.0 \%$ & 1,415 & $1.1 \%$ & -149 & $-0.1 \%$ \\
\hline Rio de Janeiro & 3,784 & $2.4 \%$ & 1,514 & $1.0 \%$ & 2,269 & $1.4 \%$ \\
\hline São Paulo & 3,237 & $0.7 \%$ & 6,695 & $1.5 \%$ & $-3,458$ & $-0.8 \%$ \\
\hline Paraná & 1,101 & $1.3 \%$ & 1,345 & $1.6 \%$ & -244 & $-0.3 \%$ \\
\hline Santa Catarina & 353 & $0.6 \%$ & 1,121 & $1.9 \%$ & -768 & $-1.3 \%$ \\
\hline Rio Grande do Sul & 1,374 & $1.5 \%$ & 1,070 & $1.1 \%$ & 304 & $0.3 \%$ \\
\hline Total & 15,917 & & 19,667 & & $-3,750$ & \\
\hline Average weighted & & $1.1 \%$ & & $1.4 \%$ & & $-0.3 \%$ \\
\hline Average unweighted & & $1.0 \%$ & & $1.4 \%$ & & $-0.4 \%$ \\
\hline
\end{tabular}

At national level, there was a shortage of trade in value added with China, i.e., Brazil was indeed a net importer of Chinese value added in 2008 as its imports surpassed its exports in US\$ 3750 million.

Concerning the Brazilian states' trade with China, Table 6 shows that only 8 out of 27 states had a positive surplus of trade in value added. Pará and notably Rio de Janeiro presented the greatest surpluses. For both states, their industry 'Mining and Quarrying' was largely responsible for the value added embodied in Chinese final use. São Paulo was also an important exporter of value added to China, but in the case of this state such value added was generated in several industries, notably those concerning services (47.2\%) and manufacturing (45.4\%). São Paulo, however, presented a shortage in its trade in value added with China. 
The largest share $(61 \%)$ of Chinese value added embodied in São Paulo's final use was generated by manufacturing industries, remarkably the industry 'Electrical and Optical Equipment', which generated US\$ 1290 million in value added directly and indirectly due to São Paulo's final use in 2008.

In contrast with the Chinese case, Table 2 indicates that in 2008 USA had a large shortage in its trade in value added. The results obtained for the Brazilian states' trade in value added with USA are summarized in Table 7 below.

Table 7 -Trade in value added with USA, Brazilian states, 2008 - million US\$

\begin{tabular}{|c|c|c|c|c|c|c|}
\hline & Exports & $\begin{array}{c}\% \text { Value } \\
\text { Added }\end{array}$ & Imports & $\begin{array}{c}\% \text { Value } \\
\text { Added }\end{array}$ & Surplus & $\begin{array}{c}\% \text { Value } \\
\text { Added }\end{array}$ \\
\hline Acre & 11 & $\overline{0.3 \%}$ & 26 & $0.8 \%$ & -15 & $-0.4 \%$ \\
\hline Amapá & 39 & $1.1 \%$ & 36 & $1.1 \%$ & 3 & $0.1 \%$ \\
\hline Amazonas & 245 & $1.2 \%$ & 612 & $3.0 \%$ & -367 & $-1.8 \%$ \\
\hline Pará & 1,712 & $5.8 \%$ & 401 & $1.4 \%$ & 1,311 & $4.5 \%$ \\
\hline Rondônia & 52 & $0.6 \%$ & 87 & $1.0 \%$ & -35 & $-0.4 \%$ \\
\hline Roraima & 6 & $0.2 \%$ & 16 & $0.7 \%$ & -10 & $-0.4 \%$ \\
\hline Tocantins & 30 & $0.5 \%$ & 61 & $1.0 \%$ & -31 & $-0.5 \%$ \\
\hline Alagoas & 102 & $1.1 \%$ & 89 & $0.9 \%$ & 13 & $0.1 \%$ \\
\hline Bahia & 1,587 & $2.8 \%$ & 828 & $1.5 \%$ & 759 & $1.3 \%$ \\
\hline Ceará & 267 & $0.9 \%$ & 304 & $1.1 \%$ & -37 & $-0.1 \%$ \\
\hline Maranhão & 368 & $1.9 \%$ & 340 & $1.8 \%$ & 29 & $0.2 \%$ \\
\hline Paraíba & 83 & $0.7 \%$ & 150 & $1.2 \%$ & -67 & $-0.5 \%$ \\
\hline Pernambuco & 225 & $0.7 \%$ & 486 & $1.5 \%$ & -260 & $-0.8 \%$ \\
\hline Piauí & 32 & $0.4 \%$ & 99 & $1.2 \%$ & -67 & $-0.8 \%$ \\
\hline Sergipe & 106 & $1.1 \%$ & 98 & $1.0 \%$ & 8 & $0.1 \%$ \\
\hline Rio Grande do Norte & 143 & $1.2 \%$ & 137 & $1.1 \%$ & 6 & $0.0 \%$ \\
\hline Distrito Federal & 91 & $0.2 \%$ & 512 & $0.9 \%$ & -421 & $-0.7 \%$ \\
\hline Goiás & 250 & $0.7 \%$ & 477 & $1.3 \%$ & -227 & $-0.6 \%$ \\
\hline Mato Grosso & 344 & $1.4 \%$ & 191 & $0.8 \%$ & 153 & $0.6 \%$ \\
\hline Mato Grosso do Sul & 173 & $1.2 \%$ & 188 & $1.2 \%$ & -14 & $-0.1 \%$ \\
\hline Espírito Santo & 1,600 & $5.5 \%$ & 690 & $2.4 \%$ & 910 & $3.1 \%$ \\
\hline Minas Gerais & 3,300 & $2.5 \%$ & 1,626 & $1.2 \%$ & 1,674 & $1.3 \%$ \\
\hline Rio de Janeiro & 2,645 & $1.7 \%$ & 2,333 & $1.5 \%$ & 312 & $0.2 \%$ \\
\hline São Paulo & 9,847 & $2.2 \%$ & 7,826 & $1.7 \%$ & 2,021 & $0.4 \%$ \\
\hline Paraná & 1,048 & $1.3 \%$ & 1,197 & $1.4 \%$ & -149 & $-0.2 \%$ \\
\hline Santa Catarina & 941 & $1.6 \%$ & 813 & $1.4 \%$ & 129 & $0.2 \%$ \\
\hline Rio Grande do Sul & 2,127 & $2.3 \%$ & 1,323 & $1.4 \%$ & 804 & $0.9 \%$ \\
\hline Total & 27,376 & & 20,945 & & 6,432 & \\
\hline Average weighted & & $2.0 \%$ & & $1.5 \%$ & & $0.5 \%$ \\
\hline Average unweighted & & $1.5 \%$ & & $1.3 \%$ & & $0.2 \%$ \\
\hline
\end{tabular}

At national level, in 2008 there were net exports of value added from Brazil to USA, with a surplus of US\$ 6423 million. In other words, USA's final use caused the generation of higher levels of value added in the industries of Brazil than the other way around.

Regarding the states' trade in value added with USA, as Table 7 shows, 14 out 27 Brazilian states presented a positive surplus. The industries 'Mining and Quarrying' and 'Basic Metals and Fabricated Metal' were crucial to the surpluses in value added presented by Pará and Minas Gerais. The largest surplus, however, corresponded to São Paulo. The São Paulo's value added embodied in the USA's final use was generated mainly in the manufacturing industries $(49.8 \%)$ and services $(36.8 \%$, with special weight of the industry 
'Post and Telecommunications; Other Business Activities'), but the industry 'Mining and Quarrying' was also responsible for a sizable share (9.7\%). Despite this surplus, São Paulo was also, by far, the state which final use embodied the greatest amount of USA's value added. Those imports of value added by São Paulo were generated mainly in manufacturing industries $(50.1 \%$, with great contribution of the industries 'Electrical and Optical Equipment' and 'Chemicals and Chemical Products') and in services (44.4\%, notably by the industry 'Post and Telecommunications; Other Business Activities').

\section{Concluding Remarks}

The fact that many of today's products and services are no longer produced within a single country raises many relevant questions. Among them, what are the effects of fragmentation of production on the distribution of income across countries, regions within countries and industries? The present paper aimed to contribute to this discussion, analyzing the generation of value added in the Brazilian states in the context of global value chains. Here, we focused on the value added variable in the spirit of the OECD-WTO 'Made in the World' initiative, which proposes 'trade in value added' as a better approach for the measurement for international trade.

Since international fragmentation of production processes leads to an interdependent structure which has to be accounted for, the input-output methodology is especially suitable. In our analysis, we combined a world input-output table from the WIOD project with an interregional input-output table. From this, in the empirical application, we obtained a model covering the interdependence of 27 Brazilian states and 40 other countries (with the rest of the world as a country) in 2008, with the economic structures arranged in 28 industries.

In our results, we observed that the average country trades approximately twice as much in value added (as a share of country's value added) than Brazil. Therefore, the participation of Brazil in the global value chain is somewhat limited. Another interesting point is that, in 2008, the trade in value added for Brazil as a whole presented a surplus close to zero, being its exports nearly equal to its imports. There is, however, heterogeneity among the Brazilian states: some states (e.g. Amazonas) present large shortages in international trade in value added, while others (e.g. Pará) present positive surpluses. Besides this, in absolute terms, states in Southeast and South dominate the Brazilian international trade in value added.

The Brazilian value chain was, then, further analyzed for the year 2008. We indicated that 16 out of 27 states presented shortages for both regional and international trade, Mato Grosso being the only state with two positive surpluses. A relevant remark is that São Paulo's surplus in regional trade does the job of balancing the transactions among Brazilian states: almost all states (Amazonas as the only exception) are net importers of value added from São Paulo.

Finally, the Brazilian states' trade in value added with China and USA, the top trade partners of the country in 2008, were analyzed displaying the results' detail level that our model can provide. It was verified that in national terms there was a shortage in trade in value added with China and a surplus with USA. However, we noticed many heterogeneities among states, both in terms of trade volume and of industries that account for the generation of value added in the states and in their trade partners.

Many other questions that were raised with the global value chains can be discussed with the model that was developed in the present paper and its underlying database. It allows for addressing issues related to other socio-economic aspects (such as employment by skill type) as well as environmental aspects (such as energy use, various emissions to air, or the use of water). Therefore, future works can greatly benefit from the model to analyze questions concerning the Brazilian states' trade relations in a global value chain. 


\section{Acknowledgement}

Part of this research was done while Erik Dietzenbacher was visiting the University of São Paulo. Financial support by the Fundação de Amparo à Pesquisa do Estado de São Paulo (FAPESP) is gratefully acknowledged.

\section{References}

BALDWIN, R. Globalization: the great unbundling(s). Economic Council of Finland. 2006. CADARSO, M.A. et al. International trade and shared environmental responsibility by sector: an application to the Spanish economy. Ecological Economics, 2012.

COSTINOT, A. et al. An Elementary Theory of Global Supply Chains. Review of Economic Studies, v. 80, pp. 109-144, 2013.

DIETZENBACHER, E. et al. The construction of world input-output tables in the WIOD project. Economic Systems Research, v. 25, pp. 71-98, 2013.

DIETZENBACHER, E. et al. Trade, Production Fragmentation, and China's Carbon Dioxide Emissions. Journal of Environmental Economics and Management, v. 64, pp. 88-101, 2012.

GROSSMAN, G.M.; ROSSI-HANSBERG, E. Trading Tasks: A Simple Theory of Offshoring. American Economic Review, v. 98, n. 5, pp. 1978-97, 2008.

GUILHOTO, J.J.M.; SESSO FILHO, U.A. Estimação da matriz insumo-produto a partir de dados preliminares das Contas Nacionais. Revista Economia Aplicada, v. 9, n. 1. abr.-jun., $2005 b$.

GUILHOTO, J.J.M. et al. Matriz de Insumo-Produto do Nordeste e Estados: Metodologia e Resultados. Fortaleza: Banco do Nordeste do Brasil, 2010.

ISARD, W. Inter-regional and Regional Input-Output Analysis: A Model of a SpaceEconomy. Review of Economics and Statistics, n. 33, pp. 319-328, 1951.

JOHNSON, R. C.; NOGUERA, G. Accounting for Intermediates: Production Sharing and Trade in Value Added. Journal of International Economics, v. 86, n. 2, pp. 224-236, 2012.

KOOPMAN, R. et al. 2010. Give Credit Where Credit Is Due: Tracing Value Added in Global Production Chains. National Bureau of Economic Research Working Paper Series No. 16426, 2010.

MILLER, R.E.; BLAIR, P.D. Input-Output Analysis: Foundations and Extensions. Cambridge University Press, 2009.

MUÑOZ, P.; STEININGER, K.W. Austria's CO2 Responsibility and the Carbon Content of its International Trade. Ecological Economics, v. 69, pp. 2003-2019, 2010.

NAKANO, S. et al. The measurement of $\mathrm{CO} 2$ embodiments in international trade: evidence from the harmonized input-output and bilateral trade database. OECD Science, Technology and Industry Working Papers, 2009.

OECD-WTO. Trade in Value-Added: Concepts, Methodologies and Challenges. 2012.

PETERS, G.P.; HERTWICH, E.G. CO2 embodied in international trade with implications for global climate policy. Environmental Science \& Technology, v. 42, n. 5, pp. 1401-1407, 2008.

SERRANO, M.; DIETZENBACHER, E. Responsibility and trade emission balances: an evaluation of approaches. Ecological Economics, v. 69, pp. 2224-2232, 2010.

TUKKER, A.; DIETZENBACHER, E. Global multiregional input-output frameworks: an introduction and outlook. Economic Systems Research, v. 25, pp. 1-19, 2013.

WIEDMANN, T. A review of recent multi-region input-output models used for consumptionbased emission and resource accounting. Ecological Economics, v. 69, pp. 211-222, 2009. 
WIEDMANN, T. et al. Examining the global environmental impact of regional consumption activities - Part 2: review of input-output models for the assessment of environmental impacts embodied in trade. Ecological Economics, v. 61, pp. 15-26, 2007.

\section{Appendix}

List of the 28 industries in the model:

\begin{tabular}{lc}
\hline Region & Number \\
\hline Agriculture, Hunting, Forestry and Fishing & 1 \\
Mining and Quarrying & 2 \\
Food, Beverages and Tobacco & 3 \\
Textiles and Textile Products & 4 \\
Leather, Leather and Footwear & 5 \\
Wood and Products of Wood and Cork & 6 \\
Pulp, Paper, Paper, Printing and Publishing & 7 \\
Coke, Refined Petroleum and Nuclear Fuel & 8 \\
Chemicals and Chemical Products & 9 \\
Rubber and Plastics & 10 \\
Other Non-Metallic Mineral & 11 \\
Basic Metals and Fabricated Metal & 12 \\
Machinery, Nec & 13 \\
Electrical and Optical Equipment & 14 \\
Transport Equipment & 15 \\
Manufacturing, Nec; Recycling & 16 \\
Electricity, Gas and Water Supply & 17 \\
Construction & 18 \\
Wholesale and retail trade & 19 \\
Hotels and Restaurants & 20 \\
Transport & 21 \\
Post and Telecommunications; Other Business Activities & 22 \\
Financial Intermediation & 23 \\
Real Estate Activities & 24 \\
Public Admin and Defence; Compulsory Social Security & 25 \\
Education & 26 \\
Health and Social Work & 27 \\
Other Community, Social and Personal Services; Private Households with Employed Persons & 28 \\
\hline
\end{tabular}


List of the 67 regions in the model:

\begin{tabular}{|c|c|c|c|c|c|}
\hline Region & Number & Region & Number & Region & Number \\
\hline Acre & 1 & Australia & 28 & Malta & 55 \\
\hline Amapá & 2 & Austria & 29 & Netherlands & 56 \\
\hline Amazonas & 3 & Belgium & 30 & Poland & 57 \\
\hline Pará & 4 & Bulgaria & 31 & Portugal & 58 \\
\hline Rondonia & 5 & Canada & 32 & Romania & 59 \\
\hline Roraima & 6 & China & 33 & Russia & 60 \\
\hline Tocantins & 7 & Cyprus & 34 & Slovak Republic & 61 \\
\hline Alagoas & 8 & Czech Republic & 35 & Slovenia & 62 \\
\hline Bahia & 9 & Germany & 36 & Sweden & 63 \\
\hline Ceará & 10 & Denmark & 37 & Turkey & 64 \\
\hline Maranhão & 11 & Spain & 38 & Taiwan & 65 \\
\hline Paraiba & 12 & Estonia & 39 & USA & 66 \\
\hline Pernambuco & 13 & Finland & 40 & RoW & 67 \\
\hline Piauí & 14 & France & 41 & & \\
\hline Sergipe & 15 & United Kingdom & 42 & & \\
\hline Rio Grande do Norte & 16 & Greece & 43 & & \\
\hline Distrito Federal & 17 & Hungary & 44 & & \\
\hline Goiás & 18 & Indonesia & 45 & & \\
\hline Mato Grosso & 19 & India & 46 & & \\
\hline Mato Grosso do Sul & 20 & Ireland & 47 & & \\
\hline Espírito Santo & 21 & Italy & 48 & & \\
\hline Minas Gerais & 22 & Japan & 49 & & \\
\hline Rio de Janeiro & 23 & Korea & 50 & & \\
\hline São Paulo & 24 & Lithuania & 51 & & \\
\hline Paraná & 25 & Luxembourg & 52 & & \\
\hline Santa Catarina & 26 & Latvia & 53 & & \\
\hline Rio Grande do Sul & 27 & Mexico & 54 & & \\
\hline
\end{tabular}

